\title{
Assisted dying: your vote counts
}

\author{
Richard Hurley features and debates editor
}

The BMJ

The BMA is currently polling members on whether it should change its opposition to doctor assisted dying. The Royal College of General Practitioners, also opposed, recently polled its members on the same question. Last year, after a poll of its members, the Royal College of Physicians changed its stance from opposition to neutrality. ${ }^{1}$

The $B M J$ has long advocated for a change in the law to give dying people the option to hasten their death if their pain were unbearable and palliation could offer no more. ${ }^{2}$ Because doctors' views diverge, we believe medical organisations should take a neutral stance: such an important decision must rest with society. The Canadian Medical Association and the Royal Australian College of General Practitioners, for example, say that their neutral stances enabled all their members, including those opposed to assisted dying, to have a voice in the public debate and to be actively involved in drafting new laws on assisted dying laws.

A proposed law put before the UK parliament in 2015 was defeated. It would have allowed doctors to prescribe lethal drugs to patients who requested them, subject to stringent safeguards. Patients would have had to take the drugs themselves. Two independent doctors and a High Court judge would have had to agree that the patient had less than six months to live, was fully informed of all the available care options, had a clear and settled intention to die, and had the mental capacity to decide voluntarily without coercion or duress. Doctors with conscientious objections would not need to be involved, the law said.

Proponents of such a law point to the fact that an average of one person a week travels from the UK to Switzerland for help to die, while many terminally ill people resort to suicide here. ${ }^{34}$ They also cite the $80 \%$ of the public who want the option for themselves and the 18 police chiefs who criticised the current law for causing "distress, confusion, and pain." ${ }^{6}$

They say that the similar law passed in Oregon more than 20 years ago works, and that some form of medical help to die is legal in eight other US states and the District of Colombia, in Victoria and Western Australia, and in Canada, Switzerland, Belgium, and the Netherlands.

On BMJ Opinion the doctors Iona Heath and Ole Hartling write that patients might feel "abandoned" by doctors if assisted dying were legal, however (http://bit.ly/2vJEadP). "Humanity's response to unbearable suffering must be more than simply eliminating the sufferer," they insist. Other opponents of a law change worry that vulnerable people could be coerced or might choose to die rather than burden their families. ${ }^{7}$ Further concerns are that assisted dying presents a threat to disabled people or a slippery slope towards wider criteria for eligibility. ${ }^{89}$

Many religious people find assisted dying at odds with their beliefs. But the former archbishop of Canterbury George Carey argues that compassionate Christians have a duty to support a law change (http://bit.ly/39VMg1R). "I would not wish to see doctors criticised for being the last group defending a status quo many now recognise is leading to great suffering," he concludes. The Royal College of General Practitioners will report the results of its poll shortly. The BMA's poll closes on 27 February, and the results will inform debate at the annual representative meeting in June.

Whatever your views, please vote in the BMA poll (www.bma. org.uk/PAD), and send us your views in a rapid response to this article. To help you, The BMJ has tried to reflect all sides of the debate on assisted dying, including testimony from doctors, patients, and families involved in places where it is permitted (https://www.bmj.com/assisted-dying).

lacobucci G. RCP adopts neutral stance on assisted dying after poll of members. $B M$ 2019;364:I1340. 10.1136/bmj.l1340 30898784

2 Delamothe T, Snow R, Godlee F. Why the Assisted Dying Bill should become law in England and Wales. BMJ 2014;349:g4349. 10.1136/bmj.g4349 24989166

3 Campaign for Dignity in Dying. One Brit travels to Switzerland for an assisted death every week, new figures reveal. Jan 2020. https://www.dignityindying.org.uk/news/one-brittravels-to-switzerland-for-an-assisted-death-every-week-new-figures-reveal.

4 Campaign for Dignity in Dying. A hidden problem: suicide by terminally ill people. Oct 2014. https://cdn.dignityindying.org.uk/wp-content/uploads/Research_FOI_Suicides.pdf. Dignity in Dying survey. Populus. https://www.populus.co.uk/poll/dignity-in-dying-2.

6 Hogg R, White S, Underhill M, et al. Open letter to Rt Hon Robert Buckland QC MP, lord chancellor and secretary of state for justice. Oct 2019. https://www.cleveland.pcc.police. uk/Document-Library/Letters/2019/Letters-from-PCC/20191024-Open-Letter-to-LordChancellor-and-SoS-for-Justice-from-PCCs.pdf.

7 Davis J, Finlay I. Would judicial consent for assisted dying protect vulnerable people?BMJ 2015;351:h4437. 10.1136/bmj.h4437 26294757

8 Campbell J. Disabled people like me fear legal assisted suicide: it suggests that some lives are less worth living. BMJ Opinion. Feb 2019. https://blogs.bmj.com/bmj/2019/02 06/disabled-people-like-me-fear-legal-assisted-suicide-it-suggests-that-some-lives-areless-worth-living.

9 Pickering M. Religious and non-religious people share objections to assisted suicide. BMJ Opinion. Jan 2019. https://blogs.bmj.com/bmj/2019/01/30/religious-and-non-religiouspeople-share-objections-to-assisted-suicide.

Published by the BMJ Publishing Group Limited. For permission to use (where not already granted under a licence) please go to http://group.bmj.com/group/rights-licensing/ permissions 
